Article

\title{
Subsidence Management System for Underground Mining
}

\author{
Lluís Sanmiquel ${ }^{\text {DD }}$, Marc Bascompta * (D), Carla Vintró and Teresa Yubero \\ Department of Mining Engineering, Industrial and ICT, Polytechnic University of Catalonia (UPC), Avenue \\ Bases de Manresa, 61-73, 08242 Manresa, Spain; lluis.sanmiquel@upc.edu (L.S.); carla.vintro@upc.edu (C.V.); \\ maria.teresa.yubero@upc.edu (T.Y.) \\ * Correspondence: marc.bascompta@upc.edu; Tel.: +34-93-877-72-42
}

Received: 15 May 2018; Accepted: 30 May 2018; Published: 7 June 2018

\begin{abstract}
Potash mining is an important economic activity in the north-east of Spain. However, one of the main environmental issues produced for such type of mining is subsidence, which generates horizontal and vertical ground displacements. A Geographic Information System (GIS)-based model is proposed as a management system in a case study with two mines. This system is able to deal with subsidence data and its behavior over time. More than 1300 control points are included in the GIS, with data since 2007. These data processed by the GIS allowed determining the module, sense and direction of the displacements, the sinking velocity and the possible affectation of subsidence to infrastructures and buildings. Hence, the system created can be a useful tool to manage subsidence data, determine its evolution, predict future environmental and social impacts and control corrective measures.
\end{abstract}

Keywords: management system; mine subsidence; geographical information system (GIS); potash mining; planning

\section{Introduction}

Mining activities play a fundamental role in the global economy since they provide vital raw materials and energy for a large number of industries. The use of minerals is extensive over the world and it comprises the production of very important products for society such as: construction industry, electrical generation, steel, agricultural products, electronic material, medicine, etc. In this way, the mining industry is a vital and strategic economic sector for many countries, including Spain. According to the Ministry of Industry, Energy and Tourism of Spain [1], there were 2942 surface and underground mines, having 24,365 people directly employed in underground mines, quarries and processing plants in 2013. However, the effects mining activities have on the surroundings receive significant global attention due to the nature of their environmental and social responsibilities [2]. Examples of potentially serious mining environmental impacts include chronic soil erosion, heavy metals overloading, acid mine drainage and subsidence [3,4]. Thus, enterprises are expected to respond positively to these challenges by assuming responsibilities.

Under this context, civil society has claimed for a more practical environmental sustainability that endorses other practices than the simple publication of green-washing reports and manuals, especially during the last 30 years [5]. Since then, companies have initiated or continued various corporate social responsibility efforts to redefine their business policies around the selection of a series of environmentally-conscious practices [6,7], and various national and international initiatives have developed frameworks for sustainability. For instance, the European Union [8] has promoted priorities based on four broad pillars (environmental protection, economic issues, social performance and employment, and research and technological development). Moreover, the Mining Association of 
Canada (MAC) developed an initiative called "Towards Sustainable Mining (TSM)" to enhance the sector's reputation by improving its environmental, social and economic performance [9].

Environmental management and performance in the mining industry has attracted much research interest and several studies have explored strategies of companies on sustainable issues [6,10-13]. Results show that an important number of mining companies have demonstrated a commitment to cleaner production and environmental management by adopting both mandatory practices (i.e., rehabilitation of mining sites and payment of taxes) and voluntary practices (i.e., environmental management systems and life cycle assessment) [14,15].

Furthermore, different authors list reasons to adopt more environmentally sustainable practices and defend that operating environmentally sensitive might be a key factor for businesses. For instance, Hilson and Murck [10] point out that the mining industry can contribute to sustainable development by minimizing the environmental and social impacts throughout its life cycle. In this direction, Driussi and Jansz [14] stand up for environmental management systems. In general, there is a great awareness in sustainable development issues, evolving into a commitment to the community where each company carries out its activity [16].

One of the unwanted consequences of mining, with effects on environment and local communities, could be subsidence [17]. It may threat safety of surface infrastructure such as motorways, railways, power-lines or telecommunications cables [18] and it can also cause major damages to buildings and houses [19]. Nowadays, most countries do not accept industrial activities without sustainability integrated in their processes, as it is stated by the development of legal regulations such as the Law of Mines and the Royal Decree 863/1985 from Spain. Therefore, the potential effects of mine subsidence should not be underestimated, but thoroughly managed in the long term. Otherwise, the mining activity may be forced into closure by social pressure due to its potential environmental impact [20,21].

The management of subsidence has increased in importance over the last two decades [22-24] and different studies have reported procedures to be applied. However, there is no standardized procedure identified, since the trend is that each engineer uses an "in-house" method [22] adapted to each specific case. Under this context, this work aims to explore the technical aspects of a management system for subsidence in a case study by means of a geographical information system (GIS), the advantages involved in its application and the potential results. ArcGIS has been chosen because of its user-friendly platform and flexibility to manage data in the long term as well as its capability of obtaining outcomes [25,26]. Moreover, the usage of GIS in mining is quite frequent, varying from management [27] to pollutants emission [28], ventilation [29] or even issues related to subsidence [30] among other applications.

\section{Mine Subsidence}

Surface subsidence is a natural consequence of underground mining [31-33] and it can be coincident with mining activities or delayed in response to the time-dependent deformation of the rock mass. Certain mining and geologic factors, including the quantity and quality of the subsoil, rock components and superficial conditions, may influence the mode, magnitude, shape and extent of subsidence [34].

Due to the potential effects of subsidence in constructions, accurate prediction techniques are needed to prevent this destruction. According to Peng [35], there are six categories of subsidence prediction methods: theoretical, profile function, influence function, empirical, physical and numerical modeling. Theoretical methods try to explain a mechanism that can predict the magnitude of subsidence; profile function methods define a number of standard functions; influence function methods are based on the effect of the extraction of infinitesimal elements of an area; empirical methods use graphs and tables; physical methods built a real model at a smaller scale than the extracted area; and numerical models use finite elements, boundary elements, distinct elements and finite difference methods to calculate the displacements and subsidence of ground surface [19]. Similarly, Bahuguna et al. [36] make a review of mine subsidence prediction methods and classify them into empirical, 
functional and mechanical. Authors analyze examples of applications of each method and discuss the merits and demerits of each.

Different authors have presented models and various papers describe the methodologies employed to analyze subsidence in different mines. For instance, Van Sambeek [31] describes the case of the Colonsay Mine in Saskatchewan, where surface subsidence is measured by optical level surveys conducted on permanent benchmarks throughout a 70-square-kilometer area above the mine. The numerical model SALT-SUBSID [37] was used for this aim. Scott and Anumba [22] developed an advisory system called SCAMS (Subsidence Case Management System), which is intended to provide a technical framework for decision making by giving engineers specific guidance for individual cases. SCAMS is an interactive computer program that consists of a knowledge-based system that incorporates judgment, experience, intuition and other expertise to provide advice about tasks. Carnec and Delacourt [38] use Synthetic Aperture Radar (SAR) interferometry to analyze the subsidence caused by underground coal mining close to Gardanne, France. Authors apply SAR technology to map surface deformations and monitor their spatial-temporal evolution $[39,40]$. However, this technology has been found insufficient to insure the accuracy enough in the case study. Asadi et al. [19] present a new profile function formed from the sum of two negative exponential functions adjusted to three survey lines for prediction of the surface subsidence profile due to inclined coal-seams in longwall mining.

Other articles assess mining subsidence and its impacts on the environment [41,42]. Bell et al. [43] analyze the effect of subsidence to the environment in six case studies to illustrate the different types of associated subsidence and related problems. Examples provided are gold mining in the Johannesburg area; board and pillar coal mining in the Witbank Coalfield, South Africa; longwall coal mining in the Ruhr district; chalk and limestone mines in Suffolk and West Midlands, respectively, and salt mines in Cheshire.

All authors agree that mining subsidence is difficult to analyze and monitor, basically due to the difficultness in expressing mathematically the variables involved. These variables include: dimensions of the holes generated, depth of the mine, mine exploitation method, nature and dip of the geological strata located in the mine and surface, etc. Topographic measurements, registered every " $n$ " months, are the fundamental data to analyze subsidence in a specific area. Nevertheless, some studies reveal a lack of systematic evaluation of subsidence in many mines, like periodical topographic measurement campaigns, which may imply a low knowledge of such phenomenon [23].

\section{Materials and Methods}

\subsection{Data Collection and Case Study}

The GIS based model was developed using data from a case study, two mines in the north-east of Spain, henceforth Mine1 and Mine2. These activities are extracting potash by means of a room and pillar method at depths between 500 and $900 \mathrm{~m}$. However, the exploitation varies considerably depending on the seams layout. There are always two mineable layers, Layer A and B, with and intermediate layer of salt of variable thickness, as it can be seen in Figure 1. When the layer of salt is more than $5 \mathrm{~m}$ thick, two drifts are used to extract sylvinite, whereas it is exploited together when the thickness has less than $5 \mathrm{~m}$. Layers A and B are interstratified layers of sylvinite salt and clay.

One of the downsides of the exploitation method used is the generation of subsidence, vertical and horizontal ground movements. Hence, surface topographic measurements have been done by means of control points distributed along the geographical area potentially affected by subsidence since 2007, obtaining the $X, Y$ and $Z$ coordinates of each point using a Global Positioning System (GPS). The method employed in the post process was the static differential with four GPS double frequency receptors. Two receptors were situated in two points of known coordinates, while other two receptors were used to perform measurements in the control points, with a minimum measurement time per point of $10 \mathrm{~min}$. This methodology guarantees an accuracy of $1-1.5 \mathrm{~cm}$ in planimetric and altimetric 
coordinates, which implies that the maximum possible error between measures from the same point is $2-3 \mathrm{~cm}$. Therefore, only higher differences are relevant to indicate if there is subsidence. Regular quality control measurements are done to verify the reliability of the method.
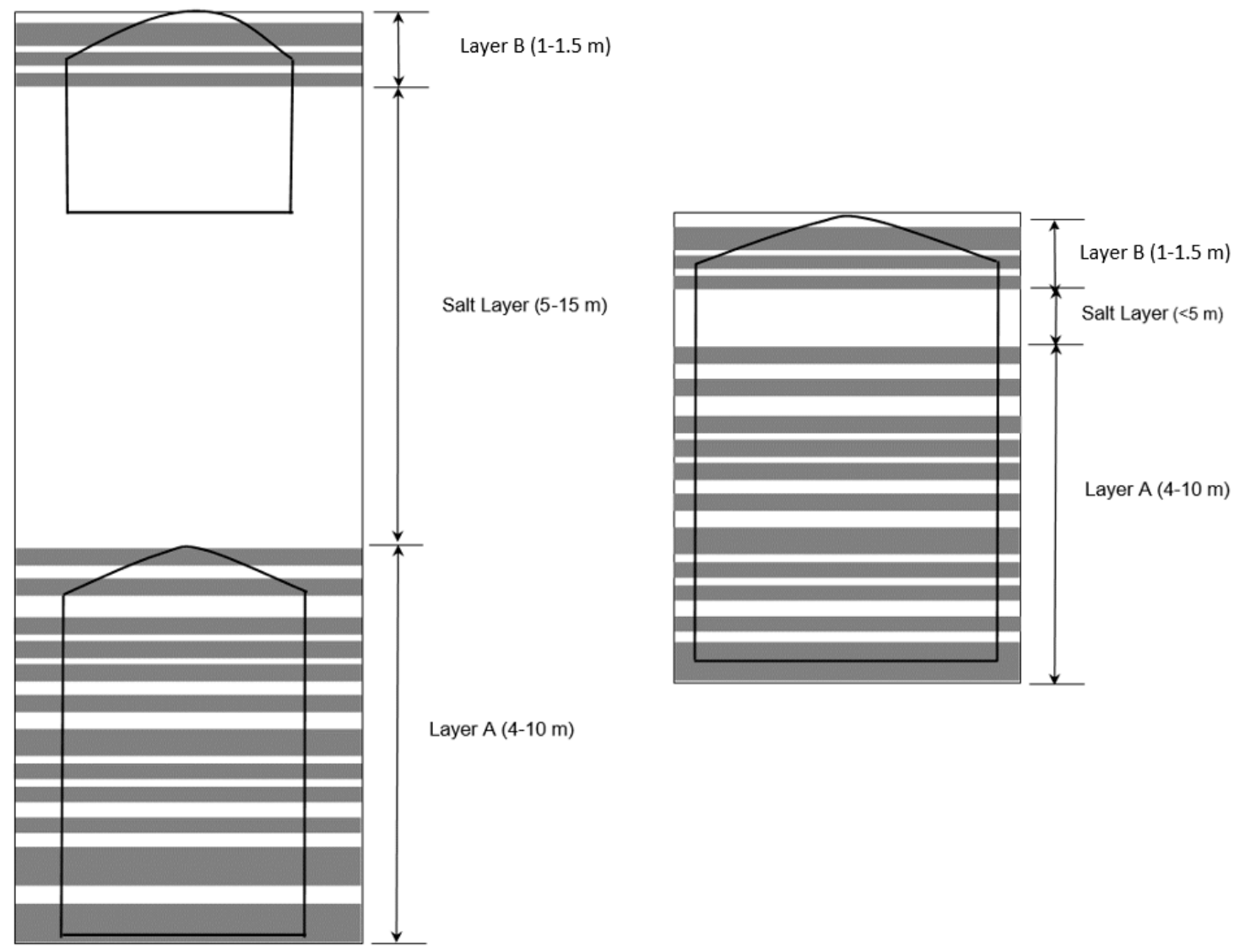

Figure 1. Seams layout and exploitation alternatives.

Mine1 has 600 control points in an area of $40 \mathrm{~km}^{2}$ with measures done in 2009, 2011, 2013 and 2015, whereas Mine2 has around 700 control points in an area of $50 \mathrm{~km}^{2}$ with measures from 2008, 2010, 2012, 2014 and 2016. The zone is predominantly forest in both cases. Based on the methodology used, the exploitation method and the geography of the zone, it was considered a minimum of 150 and 200 control points, respectively, to determine the subsidence of the whole area. In addition, there is an extra control point for each structure within the zone with potential subsidence affectation.

The system created can manage these data and determine the fundamental characteristics of the subsidence process, such as horizontal and vertical displacements over time, deformations or sinking velocity. The usage of the GIS also provides flexibility to include new parameters or extract other outcomes if it is considered necessary.

\subsection{Data Format and Characteristics}

The potential of vector and raster analysis have been included in the system proposed. Vector GIS focuses in management, whereas raster is intended for analysis [44]. The vector system allows to manage the parameters introduced and know their evolution over time, while the raster increases the potentiality of the system and the territorial and environmental analysis.

Initial data was composed by two maps, one with the control points from Mine1 and another with the points from Mine2 (both in CAD format), whereas thematic information was stored in a csv file. This information was merged and transformed to a shape file, achieving a connection between information and its corresponding position in the map. The process is shown in Figure 2, while Figure 3 
details the layers included in the GIS (mine workings, subsidence information and buildings and infrastructures) and data related to subsidence per mine and year.

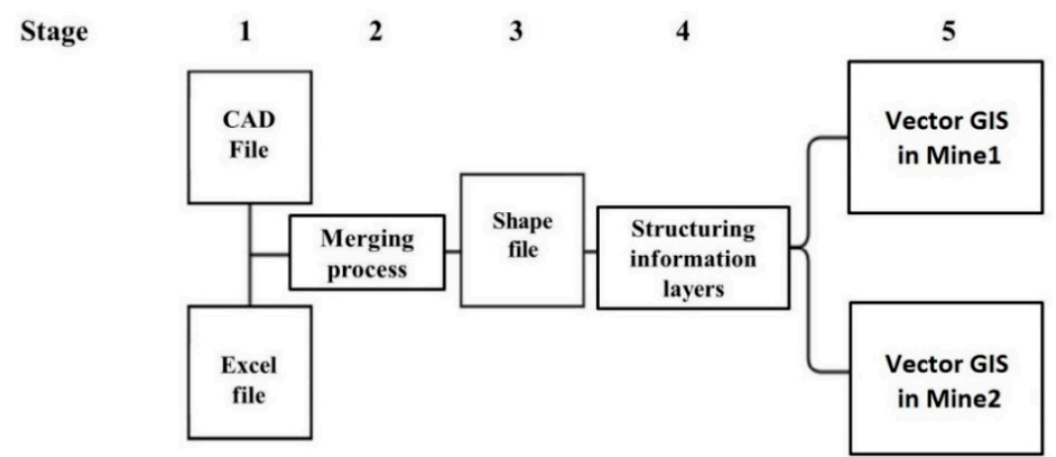

Figure 2. Scheme of the process followed to create the system.

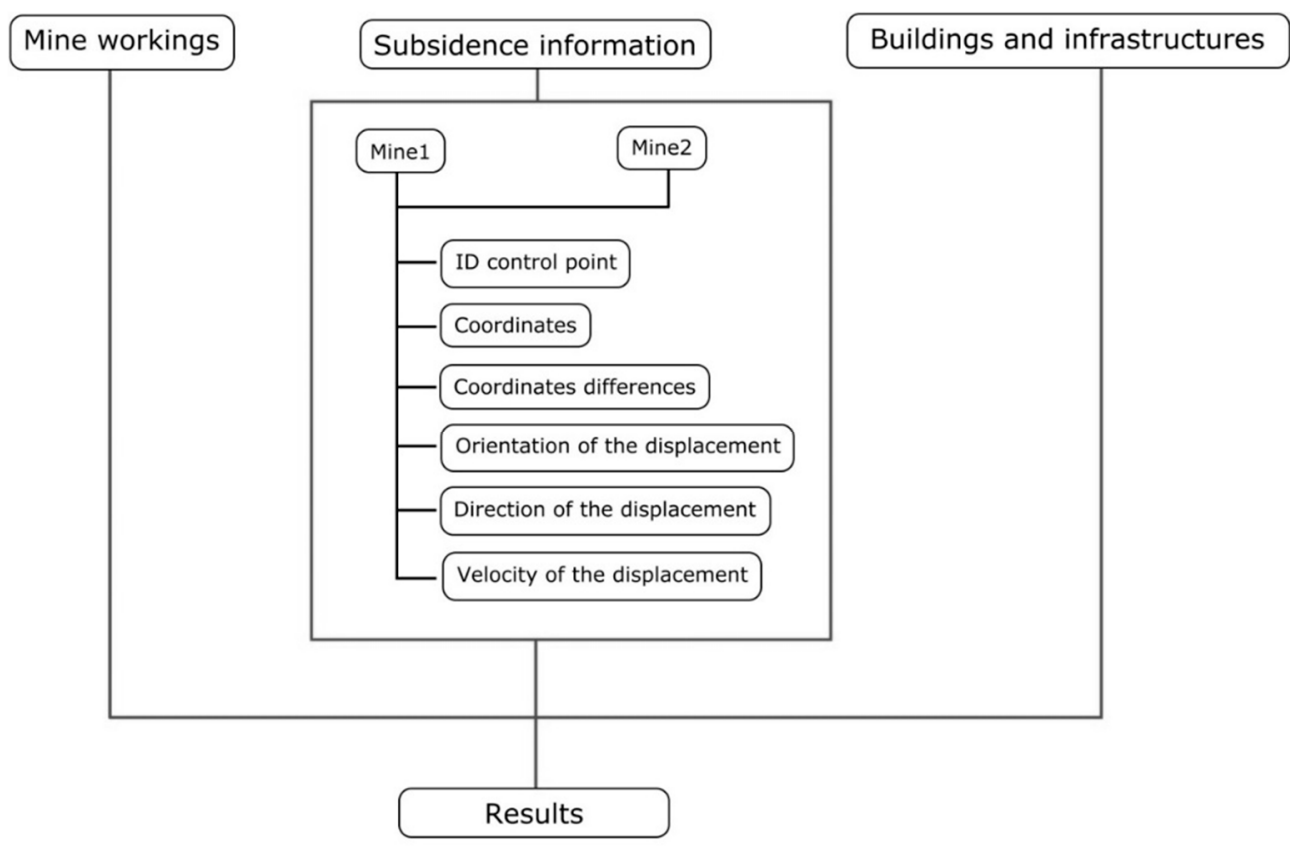

Figure 3. Model designed to manage subsidence.

This method enables to store data and compare the subsidence evolution over time easily, being able to achieve any kind of result required as long as variables are georeferenced. The potential analysis could increase as more data is collected and introduced into the GIS. Table 1 exposes all variables included in the system proposed.

These variables allow the user to manage and analyze the behavior of subsidence, such as visualize the evolution of the control points or identify which has a certain displacement or the distance to infrastructures, among many other possibilities. The combination of raster and vector GIS give the possibility to obtain other important information regarding subsidence management: The digital elevation model (DEM) was transformed to raster to obtain the horizontal displacements, $\mathrm{mm} / \mathrm{m}$, between the periods analyzed, where the value of each pixel contains the mean slope, Equation (1), corresponding to the same zone from the DEM. A modification of the algorithm from the National Coal 
Board Mining Department [45], Equations (2) and (3), was applied to know the affection of subsidence to buildings [46], determining the curvature and horizontal strain.

$$
\begin{gathered}
p=\frac{z_{i}-z_{i-1}}{x_{i}-x_{i-1}} \\
\frac{\theta}{l}=\frac{p_{i}-p_{i-1}}{x_{i}-x_{i-1}} \\
\varepsilon=\left(0.024 \cdot \frac{\theta}{l}\right)^{0.5}
\end{gathered}
$$

where $p$ is the slope, $z$ the vertical displacement at point $x, \theta / l$ the curvature and $\varepsilon$ the horizontal strain.

The algorithm has been set from the analysis of four vertical sections located in the zone of subsidence influence using the data introduced in the GIS from 2008-2016 and the ArcGIS tools. In consequence, sixteen transverse settlement profiles have been measured from the four sections (2008-2010, 2010-2012, 2012-2014 and 2014-2016). The trenches are located at depths between $500-600 \mathrm{~m}$, with width/depth $(w / h)$ ratios ranging from $0.7-1.50$. An adjustment of the Gaussian curve was carried out to the field data, obtaining a value of $i$ for each transverse of the settlement trough profile. The horizontal deformation was calculated using the values of the parameter $i$ in the following expression.

$$
\varepsilon_{h x}(x)=\frac{S_{v}(x)}{z_{0}} \cdot\left(\frac{x^{2}}{i_{x}^{2}}-1\right)
$$

where $i$ is the inflection point of the settlement trough, $\varepsilon_{h x}$ is the strain or horizontal deformation, and $S_{v}$ is the surface settlement at offset distance $x$ from the tunnel center line.

Mean values of the strains proportional to $\theta / l$ with the horizontal deformation have been obtained within reasonable limits of accuracy, and are shown on the prediction graph in Figure 4 . This figure provides a quantified relationship between deformation and $\theta / l$, as follow:

$$
\varepsilon=\left(a \cdot \frac{\theta}{l}\right)^{0.5}
$$

where $a$ varies between 0.018 and $0.012, \theta / l$ is the curvature and $\varepsilon$ the horizontal strain. A value of $a=0.018$ is used in the present study, because it is considered the worst case scenario.

Table 1. Variables of the GIS.

\begin{tabular}{cc}
\hline Variable & Type of Information \\
\hline Name of the control point & Measured \\
$X$ coordinate & Measured \\
$Y$ coordinate & Measured \\
$Z$ coordinate & Measured \\
$X$ Difference between consecutive campaigns & Calculated \\
$Y$ Difference between consecutive campaigns & Calculated \\
$Z$ Difference between consecutive campaigns & Calculated \\
Orientation of horizontal displacement & Calculated \\
Module of horizontal displacement & Calculated \\
Direction of horizontal displacement & Calculated \\
Vertical displacement velocity & Calculated \\
\hline
\end{tabular}

Raster image of the horizontal displacements, is represented in meters per each period, using the module of every control point. This information can be used to classify the hazard of subsidence to buildings [47]. Figure 5 details the hazard degree depending on the horizontal displacement. 


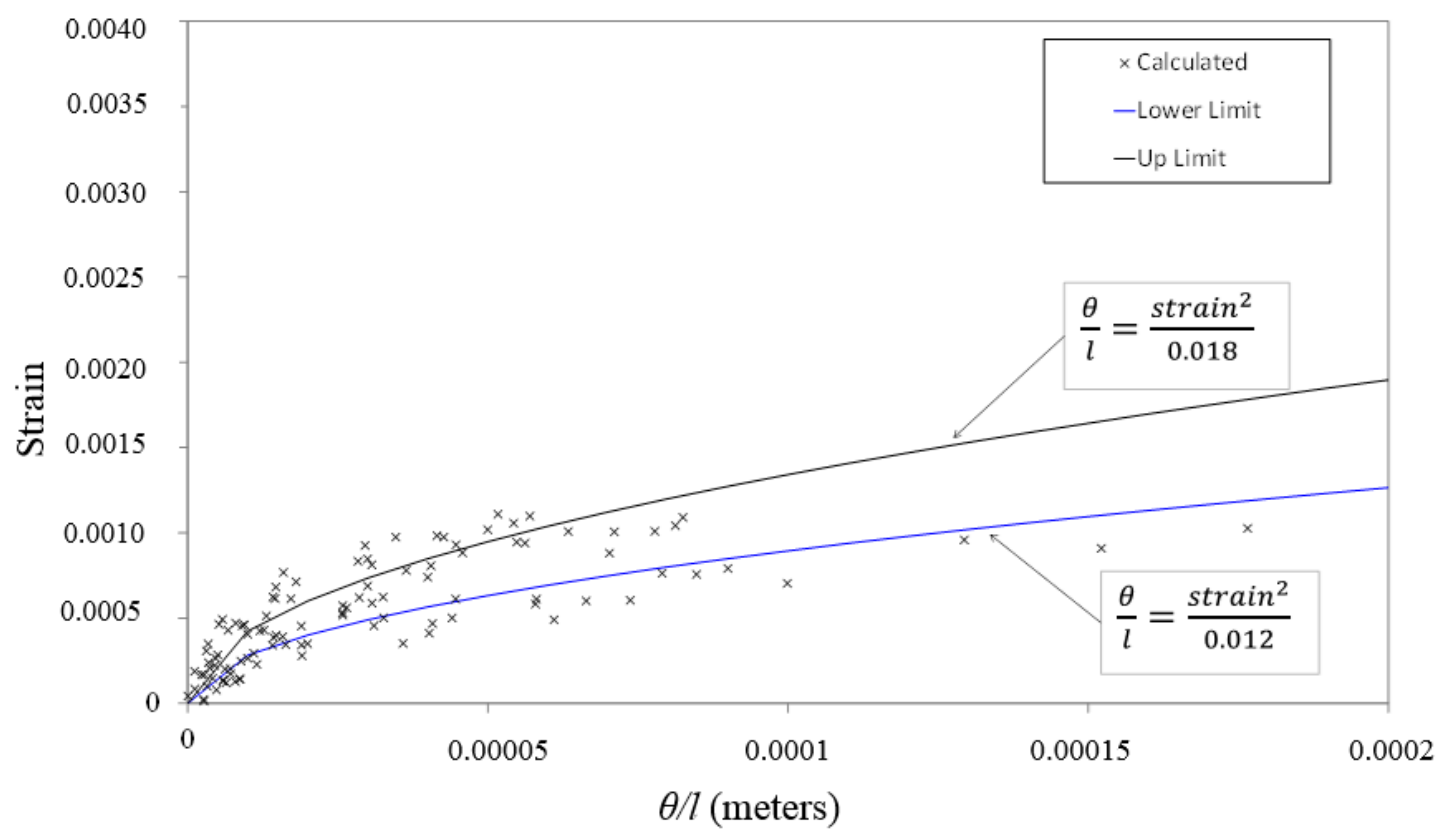

Figure 4. Relationship between strain and $\theta / l$ meters.

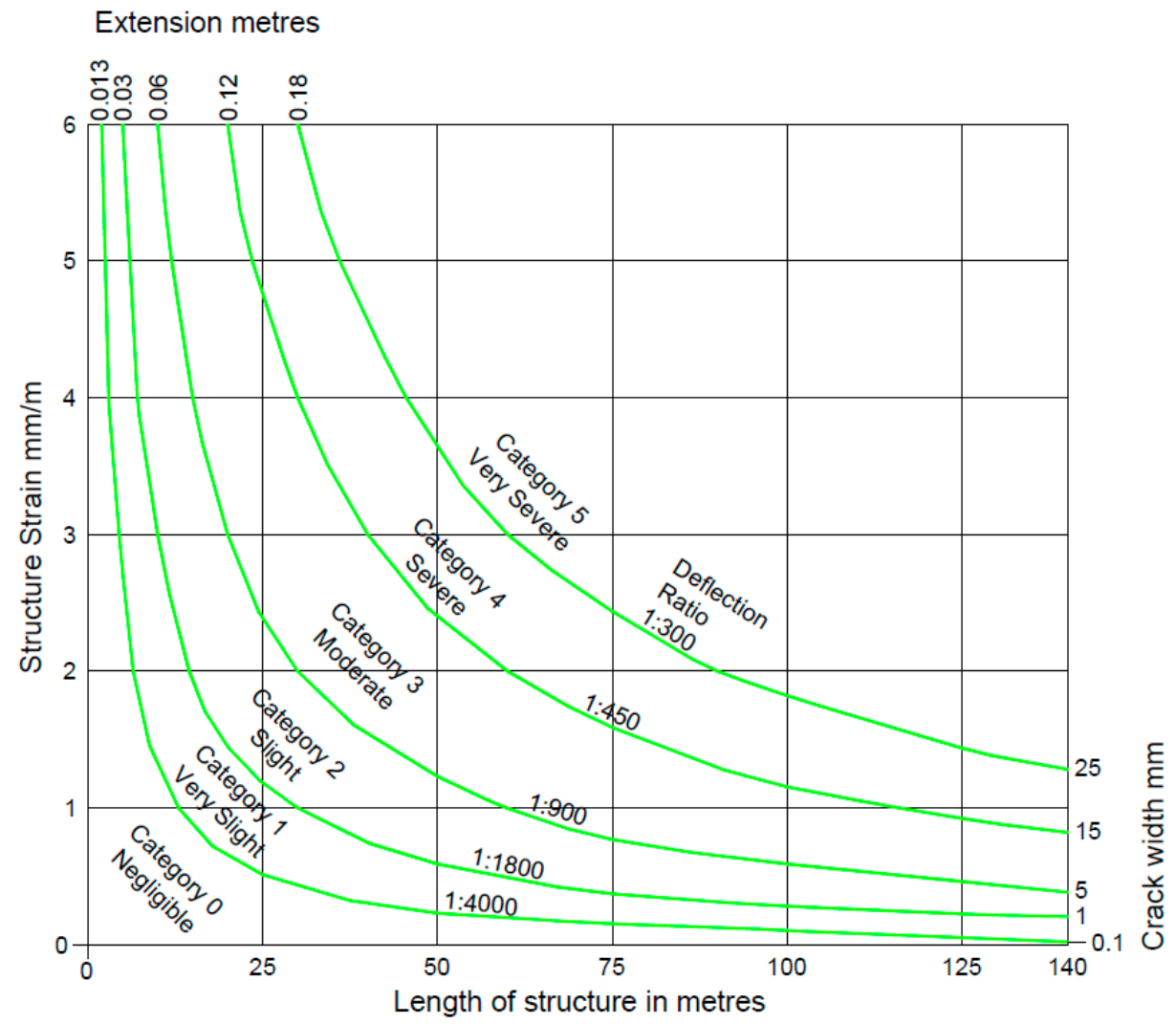

Figure 5. Impact classification with deflection ratios for two-storey brick structures [46].

\section{Results and Discussion}

The system proposed allows to obtain the results displayed below. Several vector and raster maps exposes the subsidence characteristics, either vertical and horizontal displacements or hazard level for buildings. The vector GIS is the base of the management system, while the raster GIS is 
more appropriate for territorial analysis of quantitative variables with continuous distribution like subsidence [48].

The system created can assess subsidence in different ways, such as its evolution over time by means of a contour map. Figure 6 shows the name of the control point, in black, and subsidence level, in red, as well as the contour lines every $5 \mathrm{~cm}$. Mine workings are also included to achieve better understanding of its evolution.

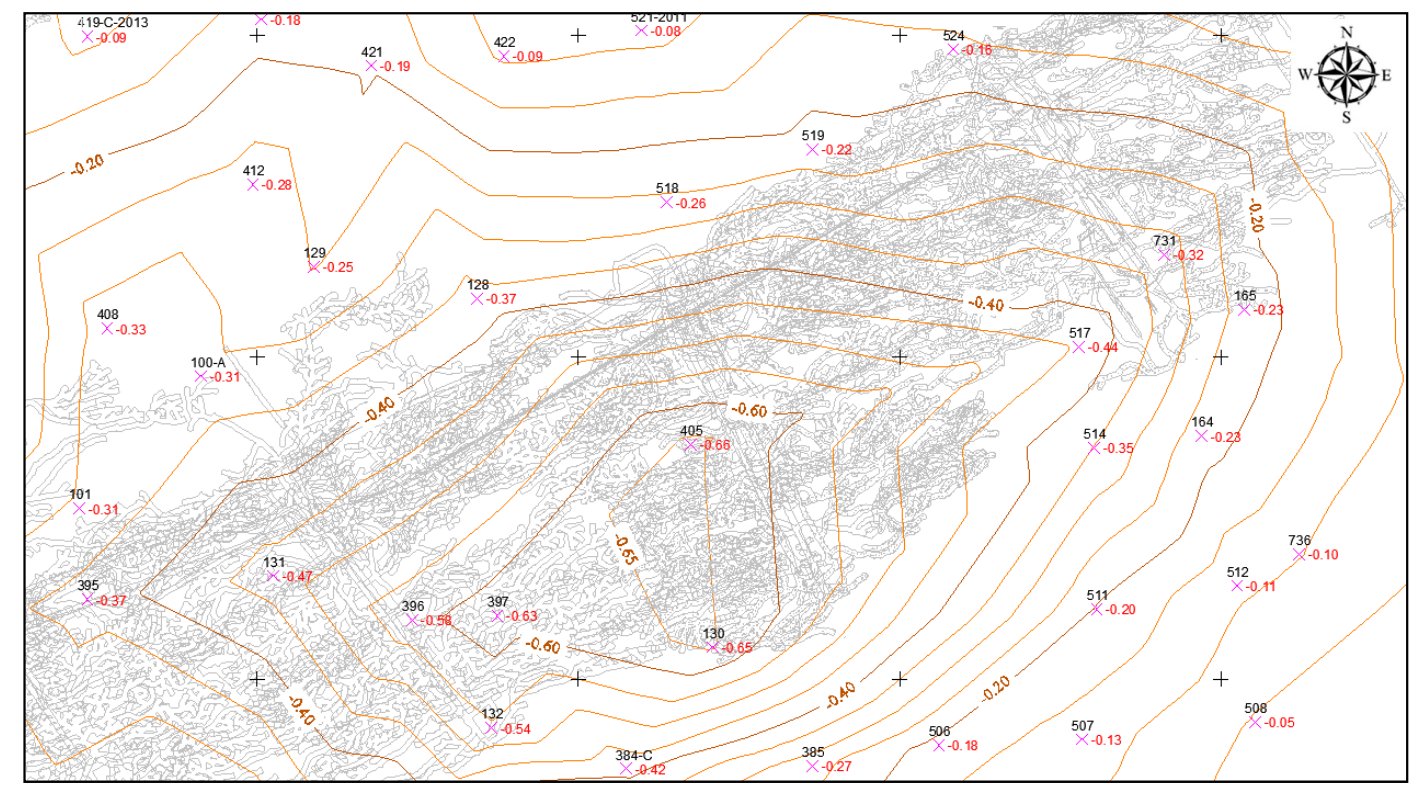

Figure 6. Vector map with the contour lines of subsidence in the most adverse zone from Mine1 between 2013 and 2015. Scale 1:10,000.

Meanwhile, Figure 7 exposes the vector with its corresponding horizontal displacement and module in the same period of time. The size of the arrow stands for the scale of horizontal displacement, between 0.04 and $0.36 \mathrm{~m}$ in this case. The versatility of the GIS provides different options to process data and achieve the outcomes required.

Figures 6 and 7 show a match between subsidence and opening of new drifts, being able to determine the time lag in both mines. The angle affecting surface-underground mine workings has also been obtained, with a mean value of $49^{\circ}$ in Mine1 and $35^{\circ}$ in Mine2. Besides, the subsoil movement was plotted to know the subsidence behavior per point, as described in Figure 8. The vertical displacement evolution in each control point over time gives the possibility to visualize the sinking velocity and make predictions for the next years. Two control points, 124 and 405 from Mine2, are detailed with the corresponding subsidence profile. The first one draws a decreasing velocity due to mine workings are moving away from it since 2009, whereas the second point is still increasing the subsidence velocity due to mine workings are very close to it.

This information can be matched with the characteristics of the area and mining workings to know the current subsoil behavior. Besides, the mine planning can be used to predict the future subsidence based on empirical information gathered in the GIS.

Moreover, the system can be inquired based on the criteria of the technician, obtaining trends, statistical data, such as mean values or the maximum and minimum subsidence generated, or applying scripts to create new parameters. This information can be matched with any other variable or layer within the GIS. For instance, Figure 9 displays the displacements higher than $20 \mathrm{~cm}$ in $X, Y$ or $Z$ between 2013 and 2017.

On the other hand, Figure 10 is a raster image, pixel size of $32 \mathrm{~m} \times 32 \mathrm{~m}$, showing the horizontal deformation in $\mathrm{mm} / \mathrm{m}$ together with a vector layer of constructions. The capability of interrelating 
raster and vector information give the possibility to analyze the most adverse zones with buildings and categorize the possible damage suffered due to horizontal and vertical deformations in $\mathrm{mm} / \mathrm{m}$. In the case study, maximum deformations due to compression and traction forces are smaller than 0.41 and $0.60 \mathrm{~mm} / \mathrm{m}$ respectively, having a negligible or very slight hazard, categories 0 and 1 according to Figure 5. The modified algorithm from the National Coal Board Mining Department [45] has been applied to calculate the horizontal deformation in $\mathrm{mm} / \mathrm{m}$ per pixel, taking into account the $a$ value obtained according to characteristics of the zone and exploitation method in the worst case scenario, as it has been exposed in the previous section.

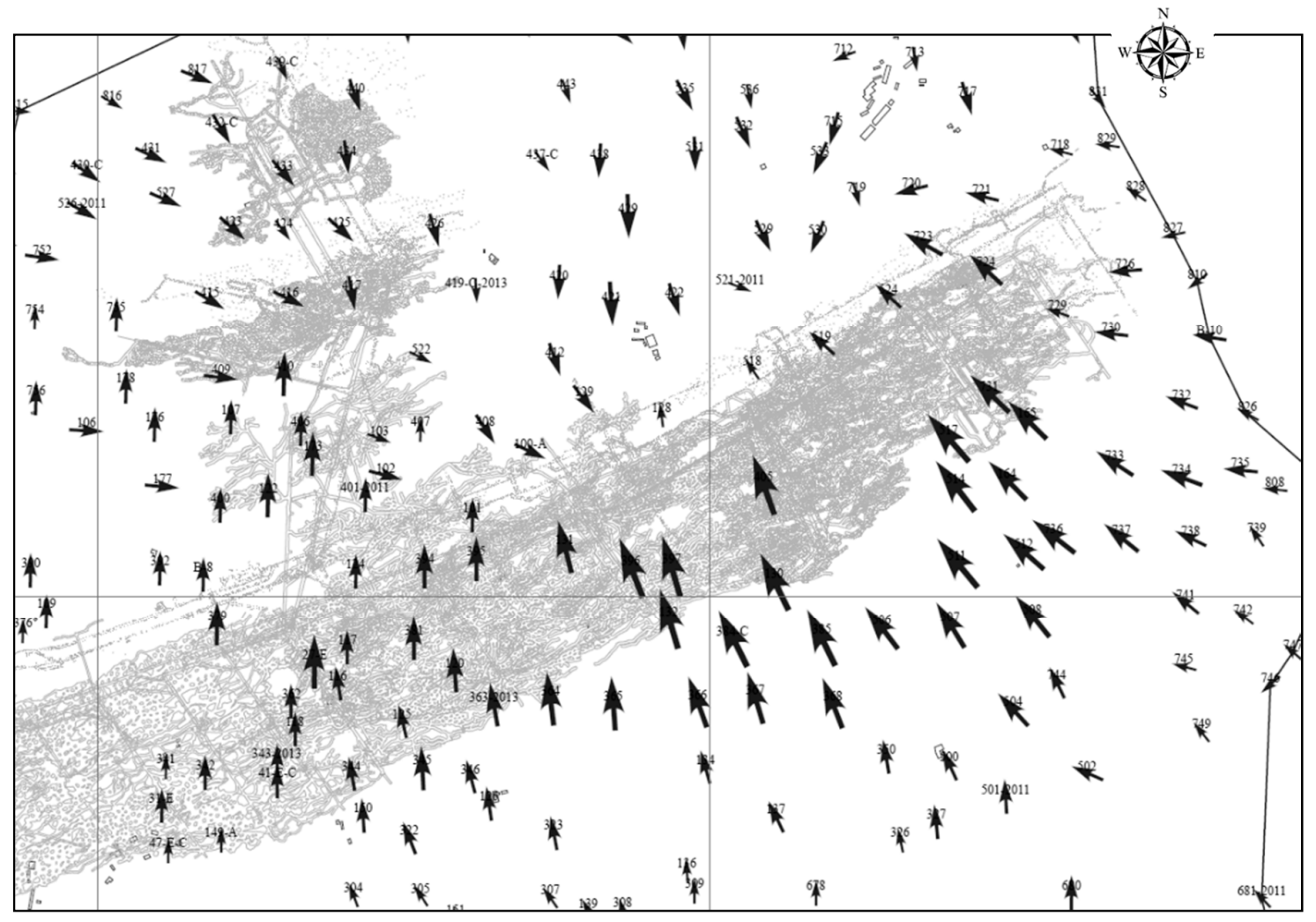

Figure 7. Vectors standing for the horizontal displacements. Scale 1:15,000.

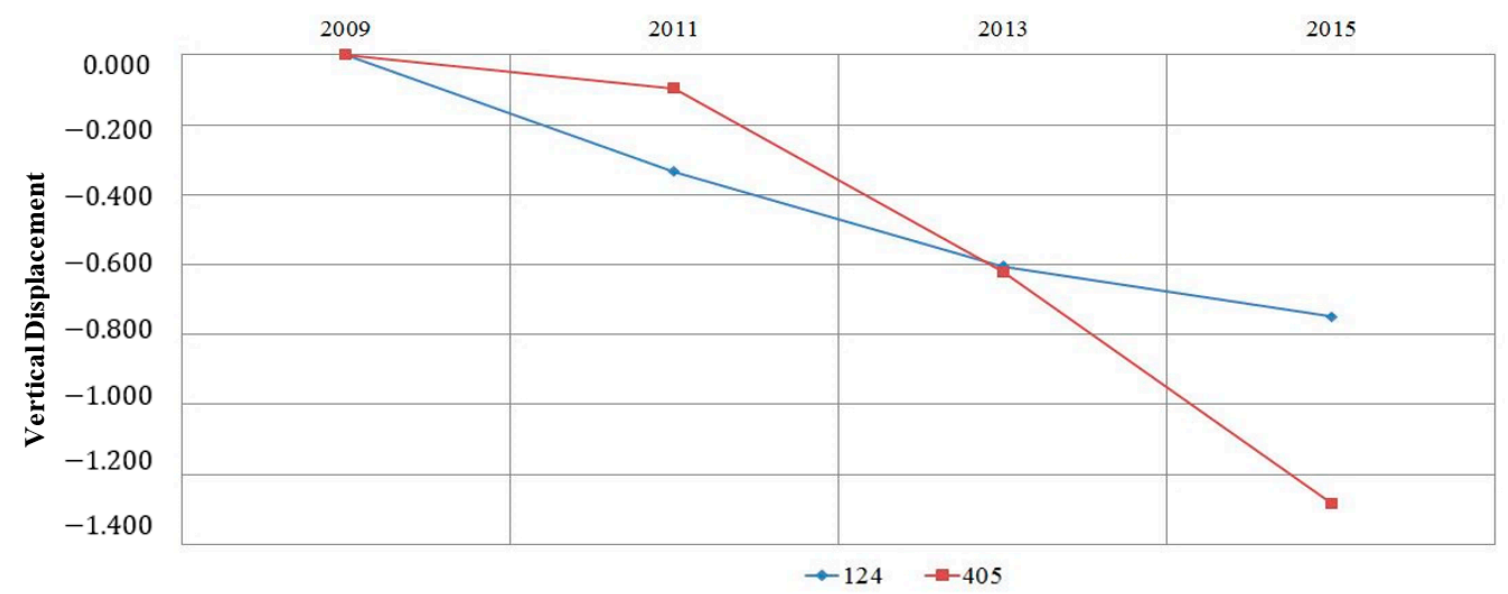

Figure 8. Vertical displacement evolution over time in points 124 and 405 from Mine 2. 


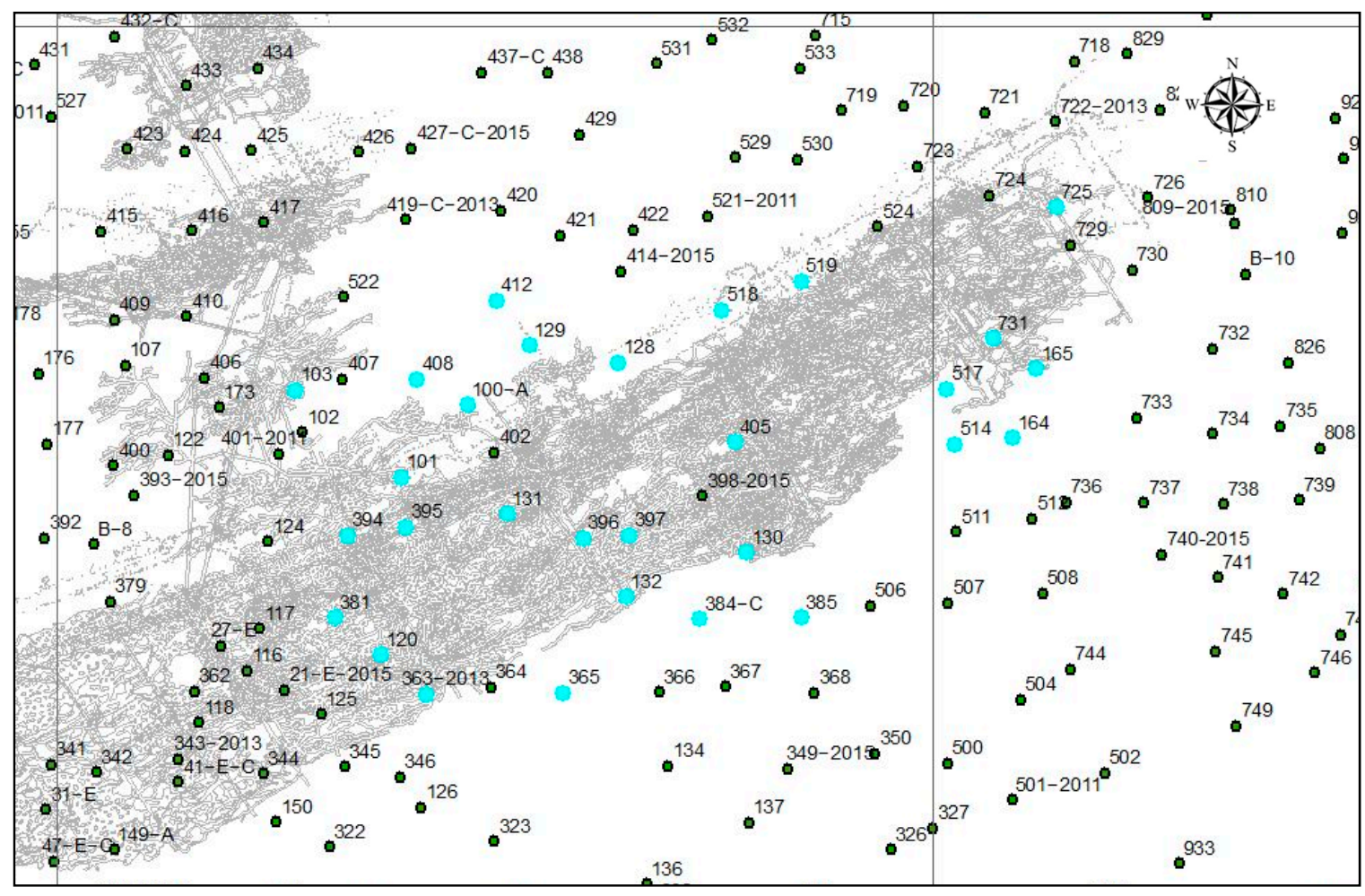

Figure 9. Control points that meet the pre-established conditions. Scale 1:12,500.

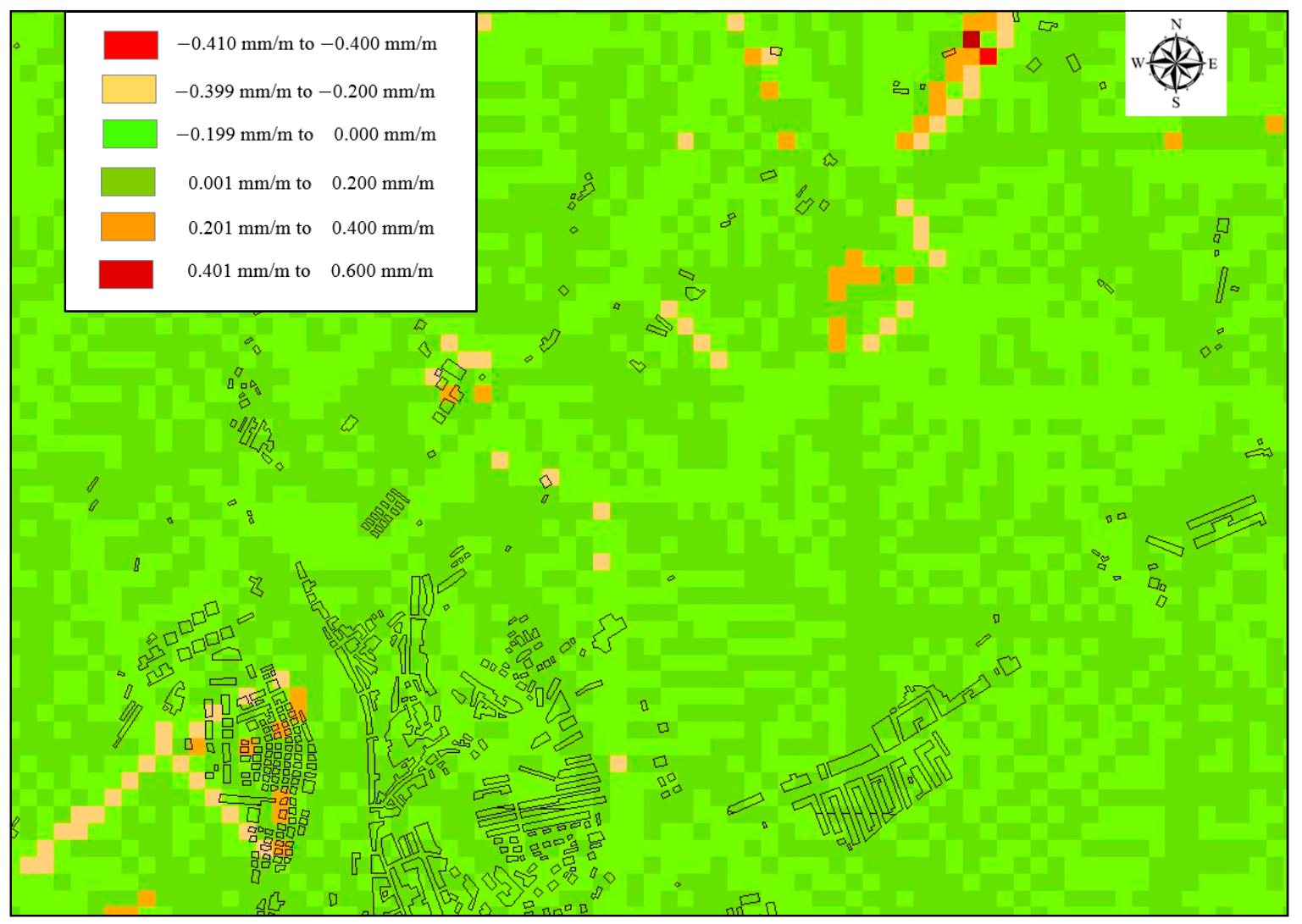

Figure 10. Raster map with the horizontal deformations, in mm/m, using Equation (5). Scale 1:15,000. 


\section{Conclusions}

The vector GIS was able to find the most affected zones by subsidence, as well as where horizontal and vertical displacements exceed a certain value. Besides, the system gives the possibility to determine the subsidence evolution between campaigns and generate subsidence profiles to know the sinking velocity in a very fast and easy way, which could help to control and manage subsidence evolution in each point or by zone. On the other hand, the raster GIS has been used to increase its potential analysis. The combination of vector and raster information has allowed us to know the subsidence impact on buildings and infrastructures. Hence, the system can also be used to predict the behavior and consequences, with the aim to take decisions and control any possible social and environmental effect in the future. In addition, any measure taken to minimize subsidence can also be assessed with the GIS. The flexibility of the system enables to modify the methodology of subsidence management or combine it with other software if it is considered necessary.

Subsidence produced by mining activity is kept within an acceptable range in terms of horizontal and vertical deformations. There are no constructions affected or any other zone with potential risk. Therefore, the exploitation method can be considered as adequate regarding this environmental impact. The subsidence velocity has also been determined, either individually per each point or by zones, being able to predict subsidence over time based on the exploitation planning and the empirical information gathered within the GIS. The system created can locate the most affected zones and provide statistical information. The time lag between the drift opening and subsidence per control point can be determined with the system as well as the angle incidence of subsidence in both mines. The system proposed has also been used to obtain a modification of the algorithm [46] for both mines.

Author Contributions: Conceptualization: L.S., M.B. and C.V.; Methodology: L.S., M.B. and T.Y.; Validation: L.S. and T.Y.; Formal Analysis: M.B. and C.V.; Investigation: L.S., M.B. and T.Y.; Writing-Original Draft Preparation: L.S., M.B. and C.V.; Writing-Review and Editing: L.S., M.B., C.V. and T.Y.

Funding: This research received no external funding.

Acknowledgments: The authors would like to thank ICL-Iberia and ICL Chair in Sustainable Mining from the Polytechnic University of Catalonia (UPC) for the data provision.

Conflicts of Interest: The authors declare no conflict of interest.

\section{References}

1. Ministry of Industry, Energy and Tourism. Annual Mining Statistics, Madrid. 2013. Available online: http: / / www.minetur.gob.es/energia/mineria/Estadistica/2013/anual\%202013.pdf (accessed on 30 June 2016).

2. Govindan, K.; Kannan, D.; Shankar, K.M. Evaluating the drivers of corporate social responsibility in the mining industry with multi-criteria approach: A multi-stakeholder perspective. J. Clean. Prod. 2014, 84, 214-232. [CrossRef]

3. Álvarez-Vigil, A.E.; González-Nicieza, C.; López Gayarre, F.; Álvarez-Fernández, M.I. Forensic analysis of the evolution of damages to buildings constructed in a mining area (Part II). Eng. Fail. Anal. 2010, 17, 938-960. [CrossRef]

4. López Gayarre, F.; Álvarez-Fernández, M.I.; González-Nicieza, C.; Álvarez-Vigil, A.E.; Herrera García, G. Forensic analysis of buildings affected by mining subsidence. Eng. Fail. Anal. 2010, 17, 270-285. [CrossRef]

5. Bruno, K.; Greer, J. The Greenpeace book of greenwashing; Greenpeace International: Washington, DC, USA, 1992.

6. Cowell, S.J.; Wehrmeyer, W.; Argust, P.W.; Robertson, J.G.S. Sustainability and the primary extraction industries. Resour. Policy 1999, 25, 277-286. [CrossRef]

7. Wirth, H.; Kulczycka, J.; Hausner, J.; Konski, M. Corporate Social Responsibility: Communication about social and environmental disclosure by large and small copper mining companies. Resour. Policy 2016, 49, 53-60. [CrossRef]

8. CEC (Commission of the European Communities). Promoting Sustainable Development in the EU Non-Energy Extractive Industry; Communication from the Commission; COM: Brussels, Belgium, 2000; p. 265. 
9. Ford, C. Towards sustainable mining: The Canadian mining industry sustainability initiative. In A Review on Indicators of Sustainability for the Minerals Extraction Industries; Bôas, R.C.V., Shields, D.J., Šolar, S.V., Anciaux, P., Önal, G., Eds.; CYTED-CETEM: Rio de Janeiro, Brazil, 2005.

10. Hilson, G.; Murck, B. Sustainable development in the mining industry: Clarifying the corporate perspective. Resour. Policy 2000, 26, 227-238. [CrossRef]

11. Warhurst, A. Corporate citizenship and corporate social investment: Drivers of tri-sector partnerships. J. Corp. Citizsh. 2001, 1, 57-73. [CrossRef]

12. Van Zyl, D.; Lohry, J.; Reid, R. Evaluation of resource management plans in Nevada using seven questions to sustainability. In Proceedings of the 3rd International Conference on Sustainable Development Indicators in the Mineral Industries, Milos Island, Greece, 17-20 June 2007; pp. 403-410.

13. Hassan, A.; Ibrahim, E. Corporate environmental information disclosure: Factors influencing companies' success in attaining environmental awards. Corp. Soc. Responsib. Environ. Manag. 2012, 19, 32-46. [CrossRef]

14. Driussi, C.; Jansz, J. Pollution minimization practices in the Australian mining and mineral processing industries. J. Clean. Prod. 2006, 14, 673-681. [CrossRef]

15. Alekseenko, V.A.; Pashkevich, M.A.; Alekseenko, A.V. Metallisation and environmental management of mining site soils. J. Geochem. Explor. 2017, 174, 121-127.

16. Blinker, L.R. Mining and the Natural Environment; UNCTAD Series of Papers on Mining, Environment and Development; UNCTAD: Geneva, Switzerland, 2009; p. 6.

17. Abdallah, M.; Verdel, T. Behavior of a masonry wall subjected to mining subsidence, as analyzed by experimental designs and response surfaces. Int. J. Rock Mech. Min. Sci. 2017, 100, 199-206. [CrossRef]

18. Ge, L.; Chang, H.-C.; Rizos, C. Monitoring Land Surface Subsidence using Radar Interferometry: The Challenges. In Proceedings of the Shaping the Change XXIII FIG Congress, Munich, Germany, 8-13 October 2006.

19. Asadi, A.; Shahriar, K.; Goshtasbi, K.; Najm, K. Development of a new mathematical modelling for prediction of surface subsidence due to inclined coal seams mining. J. South Afr. Inst. Min. Metall. 2005, 105, 15-20.

20. Laurence, D. Optimisation of the mine closure process. J. Clean. Prod. 2006, 14, 285-298. [CrossRef]

21. Prno, J.; Scott Slocombe, D. Exploring the origins of "social license to operate" in the mining sector: Perspectives from governance and sustainability theories. Resour. Policy 2012, 37, 346-357. [CrossRef]

22. Scott, D.; Anumba, C.J. A knowledge-based system for the engineering management of subsidence cases. Struct. Eng. 1999, 77, 26-31.

23. Oh, H.J.; Lee, S. Integration of ground subsidence hazard maps of abandoned coal mines in Samcheok, Korea. Int. J. Coal Geol. 2011, 86, 58-72. [CrossRef]

24. Yin, J.; Yu, D.; Wilby, R. Modelling the impact of land subsidence on urban pluvial flooding: A case study of downtown Shanghai, China. Sci. Total Environ. 2016, 544, 744-753. [CrossRef] [PubMed]

25. Wu, H.; Wang, J.; Duan, H.; Ouyang, L.; Huang, W.; Zuo, J. An innovative approach to managing demolition waste via GIS (Geographic Information System): A case study in Shenzhen City, China. J. Clean. Prod. 2015, 112, 494-503. [CrossRef]

26. Fernandez, P.; Delgado, E.; Lopez-Alonso, M.; Poyatos, J.M. GIS environmental information analysis of the Darro River basin as the key for the management and hydrological forest restoration. Sci. Total Environ. 2018, 613, 1154-1164. [CrossRef] [PubMed]

27. Düzgün, S.; Künzer, C.; Özgen Karacan, C. Applications of remote sensing and GIS for monitoring of coal fires, mine subsidence, environmental impacts of coal-mine closure and reclamation. Int. J. Coal Geol. 2011, 86, 1-2. [CrossRef]

28. Puliafito, E.; Guevara, M.; Puliafito, C. Characterization of urban air quality using GIS as a management system. Environ. Pollut. 2003, 122, 105-117. [CrossRef]

29. Bascompta, M.; Castañón, A.M.; Sanmiquel, L.; Oliva, J. A GIS-based approach: Influence of the ventilation layout to the environmental conditions in an underground mine. J. Environ. Manag. 2016, 182, 525-530. [CrossRef] [PubMed]

30. He, F.; Gu, L.; Wang, T.; Zhang, Z. The synthetic geo-ecological environmental evaluation of a coastal coal-mining city using spatiotemporal big data: A case study in Longkou, China. J. Clean. Prod. 2017, 142, 854-866. [CrossRef] 
31. Van Sambeek, L.L. Measuring Surface subsidence at Colonsay, Saskatchewan, Potash Mine. In Proceedings of the Rock Mechanics and Ground Control in the Soft Rock and Coal Industries Workshop; Canadian Institute of Mining, Metallurgy, and Petroleum: Saskatoon, SK, Canada, 1997.

32. Potts, E.L.J. Ground movement in mining areas. J. Environ. Plan. Manag. 2011, 2, 24-32.

33. Rošer, J.; Potocnik, D.; Vulic, M. Analysis of Dynamic Surface Subsidence at the Underground Coal Mining Site in Velenje, Slovenia through Modified Sigmoidal Function. Minerals 2018, 8, 74. [CrossRef]

34. Hunt, S. Surface subsidence due to coal mining in Illionis. Ph.D. Dissertation, University of Illionois, Champaign, IL, USA, 1980; p. 134.

35. Peng, S.S. Surface Subsidence Engineering; Society for Mining, Metallurgy and Exploration: Englewood, CO, USA, 1992.

36. Bahuguna, P.P.; Srivastava, A.M.C.; Saxena, N.C. A critical review of mine subsidence prediction methods. Min. Sci. Technol. 1991, 13, 369-382. [CrossRef]

37. Nieland, J.D. SALT_SUBSID: A PC-Based Subsidence Model, User's Manual; Solution Mining Research Institute: Woodstock, IL, USA, 1991.

38. Carnec, C.; Delacourt, C. Three years of mining subsidence monitored by SAR interferometry, near Gardanne, France. J. Appl. Geophys. 2000, 43, 43-54. [CrossRef]

39. Choi, J.-K.; Wom, J.-S.; Lee, S.; Kim, S.-W.; Kim, K.-D.; Jung, H.-S. Integration of a subsidence model and SAR interferometry for a coal mine subsidence hazard map in Taebaek, Korea. J. Environ. Plan. Manag. 2011, 32, 8161-8181. [CrossRef]

40. Herrera, G.; Álvarez Fernández, M.I.; Tomás, R.; González-Nicieza, C.; López-Sánchez, J.M.; Álvarez Vigil, A.E. Forensic analysis of buildings affected by mining subsidence based on Differential Interferometry (Part III). Eng. Fail. Anal. 2012, 24, 67-76. [CrossRef]

41. Yang, L.; Qiu, J.; Jiang, H.; Hu, S.; Li, H.; Li, S. Use of Cemented Super-Fine Unclassified Tailings Backfill for Control of Subsidence. Minerals 2017, 7, 216. [CrossRef]

42. Lee, S.; Park, I. Application of decision tree model for the ground subsidence hazard mapping near abandoned underground coal mines. J. Environ. Manag. 2017, 127, 166-176. [CrossRef] [PubMed]

43. Bell, F.G.; Stacey, T.R.; Genske, D.D. Mining subsidence and its effects on the environment: Some differing examples. Environ. Geol. 2000, 40, 135-152. [CrossRef]

44. Gutiérrez, J.; Gould, M. SIG: Sistemas de Información Geográfica; Editorial Síntesis: Madrid, Spain, 1994; pp. 79-81.

45. National Coal Board Mining Department. Subsidence Engineer's Handbook; National Coal Board Mining Department: London, UK, 1975; pp. 24-37.

46. Toraño, J.; Rodriguez, R.; Ramirez-Oyanguren, P. Probabilistic analysis of subsidence-induced strains at the surface above steep seam mining. Int. J. Rock Mech. Min. Sci. 2000, 37, 1161-1167. [CrossRef]

47. Mine Subsidence Engineering Consultants of Chatswood (Australia). Mine Subsidence Damage to Building Structures. 2007. Available online: http://www.minesubsidence.com/index_files/files/Mine_Subs_ Damage_to_Bldg_Structures.pdf (accessed on 30 June 2016).

48. Santos, J.M. Sistemas de Información Geográfica; UNED: Madrid, Spain, 2004; pp. 131-132.

(C) 2018 by the authors. Licensee MDPI, Basel, Switzerland. This article is an open access article distributed under the terms and conditions of the Creative Commons Attribution (CC BY) license (http://creativecommons.org/licenses/by/4.0/). 